\title{
Study on lithium dihydrogen phosphate crystal growth conditions in nonstoichiometric solutions
}

\author{
A.N.Iurchenko, A.P.Voronov, G.N.Babenko, \\ M.A.Stumbra ${ }^{*}$, V.M.Puzikov \\ Institute for Single Crystals, STC "Institute for Single Crystals"National \\ Academy of Sciences of Ukraine, 60 Lenin Ave., 61001 Kharkiv, Ukraine \\ *.Usikov Institute for Radiophysics and Electronics, \\ National Academy of Sciences of Ukraine, \\ 12 Proskura Str., 61085 Kharkiv, Ukraine
}

Received March 27, 2014

Based on analysis of lithium dihydrogen phosphate (LDP) solubility dependence on solution stoichiometry alteration, solvent evaporation rate impact on solution supersaturation change is evaluated. It is revealed that at constant crystal growth rate relative solution supersaturation linearly depends on water evaporation rate. LDP nonstoichiometric saturated solution $\left(20 \% \mathrm{H}_{3} \mathrm{PO}_{4}\right.$ excess) stability boundary conditions are determined. Water evaporation rate is $0.5 \% / 24 \mathrm{~h}$ and supersaturation $(\sigma)$ is $0.6 \% / 24 \mathrm{~h}$, respectively. LDP nonstoichiometric solutions density and viscosity are measured.

На основании анализа зависимости растворимости дигидрофосфата лития (LDP) c изменением стехиометрии раствора оценено влияние скорости испарения растворителя на изменение пересыщения в растворе. Показано, что при постоянной скорости роста кристалла относительное пересыщение в растворе линейно зависит от скорости испарения воды из раствора. Определены граничные условия стабильности нестехиометрического насыщенного раствора LDP (избыток $20 \% / 24 \mathrm{~h} \mathrm{H}_{3} \mathrm{PO}_{4}$ ). Соответствующие скорости испарения $0.5 \% \mathrm{H}_{2} \mathrm{O}$ в сутки и пересыщение $\sigma=0.6 \%$. Измерены плотность и вязкость нестехиометрических растворов LDP.

Вивчення умов вирощування монокристалів дигідрофосфату літію із нестехіометричних розчинів. А.М.Юрченко, О.П.Воронов, Г.М.Бабенко, М.О.Стулбра, В.М.Пузіков.

На основі аналізу залежності розчинності літій дигідрофосфату (LDP) зі зміною стехіометрії розчину, оцінено вплив швидкості випаровування розчинника на зміну пересичення у розчині. Показано, що при постійній швидкості росту кристала відносне пересичення у розчині лінійно залежить від швидкості випаровування води з розичну. Визначено граничні умови стабільності нестехіометричного насиченого розчину LDP (20\% надлишок $/ 24 \mathrm{~h} \mathrm{H}_{3} \mathrm{PO}_{4}$ ). Відповідні швидкості випаровуваня $0.5 \% \mathrm{H}_{2} \mathrm{O}$ за добу та пересичення $\sigma=0.6 \%$. Виміряно густину та в'язкість нестехіометричних розчинів LDP.

\section{Introduction}

During recent decades, the conditions for the growth of KDP type single crystals $\left(\mathrm{MX}_{2} \mathrm{RO}_{4}\right.$, where $\mathrm{M}=\mathrm{K}, \mathrm{Rb}, \mathrm{Cs}, \mathrm{NH}_{4} ; \mathrm{X}=\mathrm{H}$;
$\mathrm{R}=\mathrm{P}$, As) have been investigated in detail $[1,2]$. At the same time, lithium dihydrogen phosphate $\mathrm{LiH}_{2} \mathrm{PO}_{4}$ (LDP) differs from other crystals of this type by its crystalline structure and crystallization conditions 
[3-5]. LDP crystals belong to the orthorhombic crystal system, the symmetry class $P n a 2_{1}$, with the lattice parameters $a=6.241 \AA$, $b=7.643 \AA, c=6.870 \AA, Z=4$ and possess piezoelectric properties [6].

Analysis of the phase diagram of the system $\mathrm{Li}_{2} \mathrm{O}-\mathrm{P}_{2} \mathrm{O}_{5}-\mathrm{H}_{2} \mathrm{O}$ and of the processes of LDP crystal growth shows that the crystallization conditions of LDP essentially differ from those of KDP and ADP [4]. Solubility of $\mathrm{LiH}_{2} \mathrm{PO}_{4}$ at $0^{\circ} \mathrm{C}$ is 55.8 mass. \%, at temperatures higher than $20^{\circ} \mathrm{C}$ the crystals acquire incongruent solubility, i.e. $\mathrm{LiH}_{2} \mathrm{PO}_{4}$ is present in solution along with $\mathrm{Li}_{3} \mathrm{PO}_{4}$ which is present both in solution and sediment [7].

Incongruent solubility is caused by equilibrium shift in the process of dissolution towards the formation of $\mathrm{Li}_{3} \mathrm{PO}_{4}$ at temperatures above $20^{\circ} \mathrm{C}$. According to Le Chatelier's principle, such shift may be reached by rise of the solution acidity, caused by addition of excessive amounts of $\mathrm{H}_{3} \mathrm{PO}_{4}$. This results in the formation of nonstoichiometric $\mathrm{LiH}_{2} \mathrm{PO}_{4}$ solution.

Actually, according to the literature data, LDP single crystals were grown from the solutions either by the solvent evaporation [3, 7] or the temperature lowering [5] method. Thereat, the solution contained an excess of $\mathrm{H}_{3} \mathrm{PO}_{4}$ on the level of 30 mass. \%.

In the present work we investigated the conditions for the growth of LDP single crystals by the method of solvent evaporation from nonstoichiometric $\mathrm{LiH}_{2} \mathrm{PO}_{4}$ solutions, estimated the influence of the evaporation rate on the supersaturation created in the solution. The influence of the concentration of orthophosphoric acid in the mother solution on the physicochemical parameters of nonstoichiometric $\mathrm{LiH}_{2} \mathrm{PO}_{4}$ solutions was studied, too.

\section{Experimental}

$\mathrm{LiH}_{2} \mathrm{PO}_{4}$ salt was prepared from high-purity $\mathrm{Li}_{2} \mathrm{CO}_{3}$ and $85 \%$ orthophosphoric acid. The obtained powder was filtered and dried. Then there were prepared saturated nonstoichiometric $\mathrm{LiH}_{2} \mathrm{PO}_{4}$ water solutions containing excess of orthophosphoric acid with $20,40,50,60,75$ and 85 mass \% concentrations of $\mathrm{H}_{3} \mathrm{PO}_{4}$. The temperature dependences of $\mathrm{LiH}_{2} \mathrm{PO}_{4}$ solubility and the solubility isotherms were determined by the methods of test seeds and isothermal saturation, respectively.

The acidity of saturated $\mathrm{LiH}_{2} \mathrm{PO}_{4}$ solution was measured on a pH-meter. The density and viscosity of the solutions was deter-

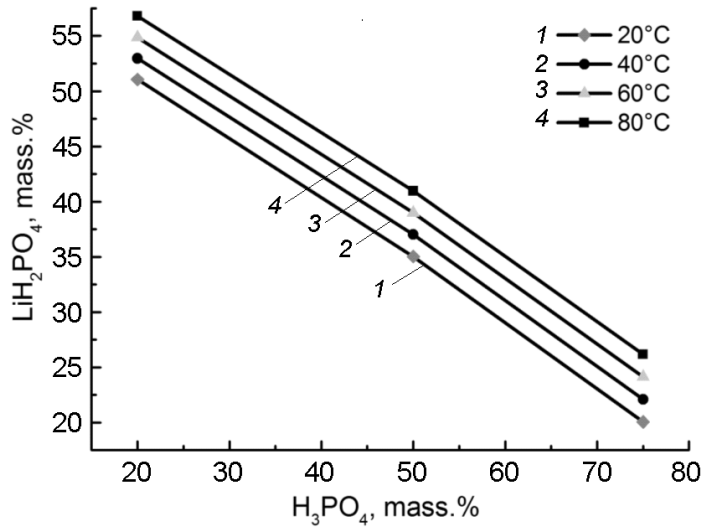

Fig. 1. $\mathrm{LiH}_{2} \mathrm{PO}_{4}$ solubility isotherms in $\mathrm{H}_{3} \mathrm{PO}_{4}$ water solutions at $20,40,60$ and $80^{\circ} \mathrm{C}$.

mined under temperature-stabilized conditions using areometers and capillary viscometers, respectively.

\section{Results and discussion}

Physicochemical parameters of nonstoichiometric LDP solutions.

The isotherms of $\mathrm{LiH}_{2} \mathrm{PO}_{4}$ solubility in $\mathrm{H}_{3} \mathrm{PO}_{4}$ water solutions of different concentrations are presented in Fig. 1. As is seen, the curves are located rather close to each other, that testifies to the fact that the temperature dependence of $\mathrm{LiH}_{2} \mathrm{PO}_{4}$ solubility is insignificant [8]. With alteration of the solution stoichiometry (of the acid concentration in the solution), solubility of $\mathrm{LiH}_{2} \mathrm{PO}_{4}$ changes in wider limits than it is observed with temperature changes. In particular, the slope ratio of the temperature dependence of solubility is more than five times less in magnitude than the slope of the dependence of $\mathrm{LiH}_{2} \mathrm{PO}_{4}$ solubility on the concentration of orthophosphoric acid: 0.1 mass $\% \mathrm{LiH}_{2} \mathrm{PO}_{4} /{ }^{\circ} \mathrm{C}$ and -0.56 mass. $\%$ $\mathrm{LiH}_{2} \mathrm{PO}_{4} /$ mass. $\% \mathrm{H}_{3} \mathrm{PO}_{4}$, respectively. The negative sign reflects the fact that the solubility diminishes with the rise of the concentration of phosphoric acid, and this can be used for creating supersaturation in the growth solution and for crystal growth.

Numerical estimations show that at the decrease of the solvent temperature from 80 to $20^{\circ} \mathrm{C}$ one can grow the crystals with a weight up to $6 \%$ of the mass of the solution. At the same time, the rise of the acid concentration in the mother solution from 20 to 50 mass. \% allows increasing the yield of the crystalline substance to $11 \%$ of the initial mass of the solution.

As is known, the density and viscosity of the solution are necessary parameters for 


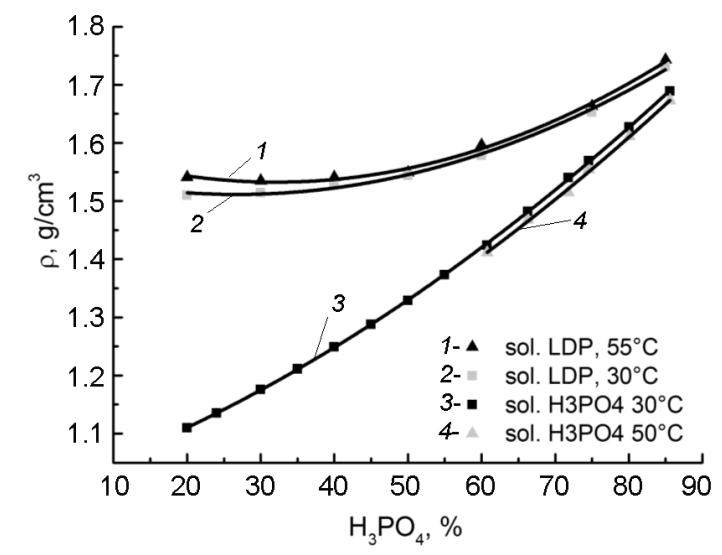

Fig. 2. $\mathrm{LiH}_{2} \mathrm{PO}_{4}$ saturated solutions density dependences on $\mathrm{H}_{3} \mathrm{PO}_{4}$ concentration at 30 and $55^{\circ} \mathrm{C}\left(\mathrm{H}_{3} \mathrm{PO}_{4}\right.$ water solutions density is given for comparison [10]).

the choice of operating practices of crystal growth. We measured the density and viscosity of nonstoichiometric $\mathrm{LiH}_{2} \mathrm{PO}_{4}$ solutions depending on excess of orthophosphoric acid in the solution. Fig. 2 and 3 present the dependences of the density and viscosity of saturated $\mathrm{LiH}_{2} \mathrm{PO}_{4}$ solutions on the concentration of orthophosphoric acid in the solution at temperatures of 30 and $55^{\circ} \mathrm{C}$. As is seen, the density of the saturated solutions rises with the rise of the acid content (Fig. 2) due to the increasing contribution of the acid to the total density (ranging between 1.51 and $1.73 \mathrm{~g} / \mathrm{cm}^{3}$ at $\left.30^{\circ} \mathrm{C}\right)$. As the temperature grows, the density of the saturated solutions rises insignificantly, since the solubility of $\mathrm{LiH}_{2} \mathrm{PO}_{4}$ slightly depends on the temperature. Moreover, the figure shows that the increase of the acid concentration in the solution weakens the temperature dependence of the solution density due to diminution of $\mathrm{LiH}_{2} \mathrm{PO}_{4}$ solubility.

As seen from Fig. 3, with the increase of the acid concentration in the saturated solution, its viscosity diminishes at first due to the decreasing contribution of the dissolved salt to the value of viscosity, and then it increases due to the rising contribution of orthophosphoric acid to the solution viscosity. Thus, at $30^{\circ} \mathrm{C}$ the viscosity of saturated $\mathrm{LiH}_{2} \mathrm{PO}_{4}$ solution changes within $5 \div 9 \mathrm{mPa} \cdot \mathrm{s}$. At the rise of the temperature, the viscosity goes down, and the region of elevated viscosity at a minimal acid concentration becomes not so pronounced. This testifies to the fact that the temperature dependence of the viscosity of saturated $\mathrm{LiH}_{2} \mathrm{PO}_{4}$ solution based on $20 \% \mathrm{H}_{3} \mathrm{PO}_{4}$ is more expressed

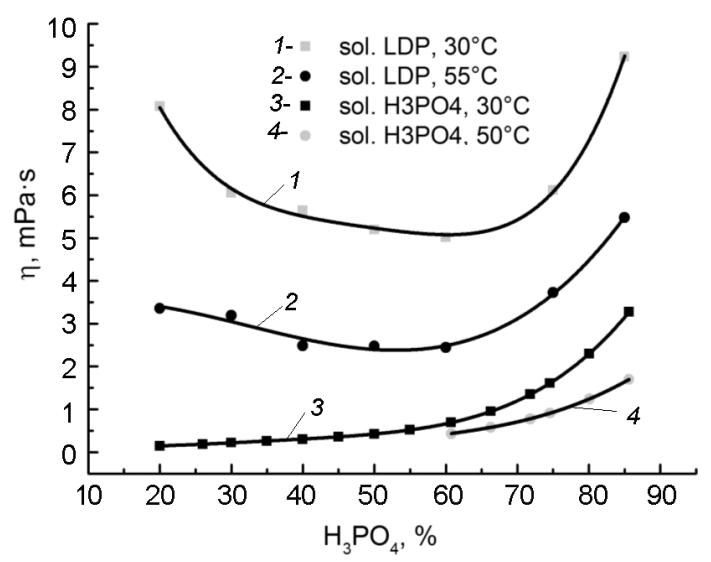

Fig. 3. $\mathrm{LiH}_{2} \mathrm{PO}_{4}$ saturated solutions viscosity dependences on $\mathrm{H}_{3} \mathrm{PO}_{4}$ concentration at 30 and $55^{\circ} \mathrm{C}\left(\mathrm{H}_{3} \mathrm{PO}_{4}\right.$ water solutions viscosity is given for comparison [11]).

than the one of orthophosphoric acid water solutions. This is evidently connected with the fact that saturated $\mathrm{LiH}_{2} \mathrm{PO}_{4}$ solution is highly concentrated, and a close location of bulky hydrated ions raises the solution viscosity [11]; as the temperature increases the kinetic energy of the ions goes up thus diminishing the viscosity.

Conditions of LDP crystallization from nonstoichiometric solutionsю

At the growth of LDP single crystals by the method of solvent evaporation, supersaturation in the mother solution is created mainly due to evaporation of water, since water vapor tension is by far higher in comparison with that of $\mathrm{H}_{3} \mathrm{PO}_{4}$ and $\mathrm{LDP}$ vapors [12]. Thereat, the volume of the solvent and the concentration of $\mathrm{H}_{3} \mathrm{PO}_{4}$ in the solution change simultaneously. Numerical estimations (made on the assumption that a half of the water contained in the solution based on $20 \% \mathrm{H}_{3} \mathrm{PO}_{4}$ at $50^{\circ} \mathrm{C}$ evaporates) show that in the crystallization process, water evaporation together with increase of the acid concentration may raise the yield of the crystalline substance up to $30 \%$ of the solution mass, i.e. threefold as much as that obtained at increasing only the acid concentration.

As is known, the rate of evaporation of a liquid depends on the evaporation area, atmospheric pressure, vapor tension of the liquid and their partial pressure over the evaporation surface [13]:

$$
U=C S_{e v a p} / P_{0}\left(P_{p}-P\right)
$$

where $U$ is the evaporation rate; $S_{\text {evap }}$ is the evaporation area; $P_{0}$ is atmospheric pres- 
sure; $P_{p}$ is water vapor tension; $P$ is water vapor partial pressure; $C$ is constant.

As seen from Eq. (1), one can control the evaporation rate by changing either the water vapor tension, or their partial pressure. The former value increases with the rise of the solution temperature [12], the latter can be controlled by altering the gas pressure over the solution surface.

The crystal growth rate depends on the solution supersaturation value and rises with its increase [14]. Therefore, the rate of water evaporation is the main factor, which defines the crystal growth rate.

The influence of the water evaporation rate on the change of solution supersaturation was estimated by analyzing the LDP solubility dependence on the solution stoichiometry. The solubility isotherm linearly depends on the acid concentration in the solution and is approximated by the equation:

$$
\omega(L D P)=-0.5647 \cdot \omega\left(\mathrm{H}_{3} \mathrm{PO}_{4}\right)+0.6529,(
$$

where: $\omega(\mathrm{LDP})$ and $\omega\left(\mathrm{H}_{3} \mathrm{PO}_{4}\right)$ are the mass concentrations of $\mathrm{LDP}$ and $\mathrm{H}_{3} \mathrm{PO}_{4}$ in the solution at a given temperature.

If we replace the values of LDP solubility and acid concentration in this equation by the corresponding expressions for determination of the weight concentrations of LDP salt $\omega(\mathrm{LDP})=m(\mathrm{LDP}) /\left[m\left(\mathrm{H}_{2} \mathrm{O}\right)+m\left(\mathrm{H}_{3} \mathrm{PO}_{4}\right)+m(\mathrm{LDP})\right]$ and orthophosphoric acid $\omega\left(\mathrm{H}_{3} \mathrm{PO}_{4}\right)=$ $m\left(\mathrm{H}_{3} \mathrm{PO}_{4}\right) /\left[m\left(\mathrm{H}_{3} \mathrm{PO}_{4}\right)+m \mathrm{H}_{2} \mathrm{O}\right]$, we will obtain a quadratic equation. Its solution with respect to the mass of LDP yields the expression for the dependence of the mass of LDP in the solution on the mass of water.

Numerical calculations of LDP mass in the solution dependence on remaining water mass after water evaporation for certain period of time make it possible to estimate the influence of the rate of water evaporation on the change in solution supersaturation. Solution relative supersaturation is defined by the well-known expression [15]:

$$
\sigma=\left(C-C_{0}\right) / C_{0},
$$

where $C$ is the current value of the LDP concentration in the solution, $C_{0}-$ the equilibrium concentration value. At isothermal evaporation of the solvent the concentration values in this expression can be replaced by the value of LDP mass in the solution at the initial and the finite (after evaporation) moments of time. If the diminution rate of the LDP mass in the solution is constant (con-

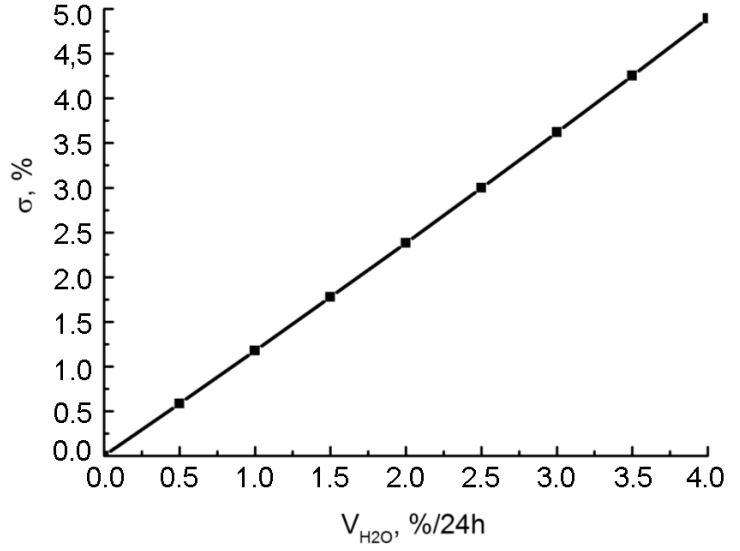

Fig. 4. Dependence of relative supersaturation, caused by isothermal solvent evaporation in $\mathrm{LiH}_{2} \mathrm{PO}_{4}$ solution, on the rate of water evaporation.

stant crystal growth rate), and if one expresses the water evaporation rate in percent of water mass decrease relatively to initial water content, then one can calculate the dependence of the created supersaturation on the water evaporation rate. Fig. 4 presents the graph of this dependence. For the shown interval, it is well approximated by a linear function, and allows calculating the LDP crystal growth conditions using the method of solvent evaporation by changing the partial pressure of water vapors over the solution surface.

The influence of evaporation rate on the LDP crystal growth was studied for the solution based on $20 \% \mathrm{H}_{3} \mathrm{PO}_{4}$. In this case, the salt has the highest solubility, in addition, it is a sufficient acid excess for congruent LDP dissolution. The growth temperature was chosen proceeding from the temperature dependence of water vapor tension [12]. At temperatures above $50^{\circ} \mathrm{C}$, during $24 \mathrm{~h} 1 \%$ of water evaporated even in the absence of forced evaporation, which allowed creating $\sim 1.2 \%$ supersaturation in the solution. Thereat, the solution became unstable and several days later, it was found to contain parasitic inclusions due to mass crystallization. At $40^{\circ} \mathrm{C}$, the water vapor tension over the solution surface became less by half, and without forced evaporation, the solvent practically did not evaporate. The chosen regime of forced evaporation implied a maximum rate of water evaporation of $0.5 \%$ of $\mathrm{H}_{2} \mathrm{O} / 24 \mathrm{~h}$ without loss of the solution stability. Thereat, the value of supersaturation was $\sim 0.6 \% / 24 \mathrm{~h}$. 


\section{Conclusions}

Nonstoichiometric $\mathrm{LiH}_{2} \mathrm{PO}_{4}$ solution for the growth of LDP single crystals by the solvent evaporation method are investigated. The analysis of the dependence of LDP solubility on the solution stoichiometry allows obtaining the dependence of LDP mass in the solution on the water mass in the solution. The preformed calculations show that at a constant crystal growth rate relative supersaturation in the solution linearly depends on the rate of water evaporation from the solution. The boundary conditions of nonstoichiometric saturated $\mathrm{LiH}_{2} \mathrm{PO}_{4}$ solution stability are determined for 20 mass. $\%$ of $\mathrm{H}_{3} \mathrm{PO}_{4}$ : the water evaporation rate and relative solution supersaturation must not exceed $0.5 \% / 24 \mathrm{~h}$ and $0.6 \% / 24 \mathrm{~h}$, respectively.

The concentration and temperature dependences of the density and viscosity of nonstoichiometric LDP solutions are measured. As the concentration of $\mathrm{H}_{3} \mathrm{PO}_{4}$ in the solution rises from 20 to $85 \%$, the solution density increases from 1.51 to $1.73 \mathrm{~g} / \mathrm{cm}^{3}$ at $30^{\circ} \mathrm{C}$, the viscosity changes within $5 \div 9 \mathrm{mPa} \cdot \mathrm{s}$ range.

\section{References}

1. V.N.Portnov, E.V.Chuprunov, Kinetika i Morfologiya Dislokatsionnogo Rosta Granei Kristallov iz Rastvora, Uchebnoye Posobie, Izd-vo Nizhegorodskogo Gosuniversiteta, Nizhny Novgorod (2010) [in Russian].

2. I.M.Pritula, V.I.Salo, M.I.Kolybaeva, Inorganic Materials, 37, 184 (2001).
3. M.Catti, G.Ivaldi, Zeitschrift fur Kristallographie, 146, 215 (1977).

4. K.-S.Lee, I.-H.Oh, J.J.Kweon et al., Mater. Chem. and Phys., 136, 802 (2012).

5. L.V.Soboleva, I.L.Smolsky, Crystallogr.Reports, 42, 700 (1997).

6. S.Haussuhl, Cryst.Res.Technol., 31, 323 (1996).

7. A.B.Rollet, R.Zaufenburger, Bull.Soc.Chim. France, 5, 146 (1934).

8. A.P.Voronov, G.N.Babenko, V.M.Puzikov, A.N.Iurchenko, J. Cryst. Growth, 374, 49 (2013).

9. J.Clarence (West), W.Edward (Washburn), N.Ernest (Dorsey), National Research Council (U.S.) and Knovel (Firm) International Critical Tables of Numerical Data, Phys., Chem. and Techn. (1st electronic ed), Knovel, Norwich, N.Y (2003).

10. T.D.Farr, Phosphorus-Properties of the Element and Some of Its Compounds, Chemical Engineering Report, No.8, Tennessee Valley Authority, Muscle Shoals, AL, 1950, reprinted 1966.

11. A.Bondi, Ann. New York Academy Sci., 53, 870 (1951).

12. A.I.Volkov, I.M.Zharskiy, Bolshoy Khimicheskiy Spravochnik, Sovremennaya Shkola, Minsk (2005) [in Russian].

13. B.M.Yavorskiy, A.A.Detlaf, Spravochnik po Fizike. Dlya Inzhenerov I Studentov VUZov, Nauka, Moscow (1968) [in Russian].

14. A.A.Chernov, Modern Crystallography III, Crystal Growth, Springer, Berlin (1984).

15. V.N.Portnov, E.V.Chuprunov, Vozniknoveniye i Rost Kristallov, Uchebnoye Posobiye dlya VUZov, Izd-vo Fiziko-matematicheskoi Literatury, Moscow (2006) [in Russian]. 